
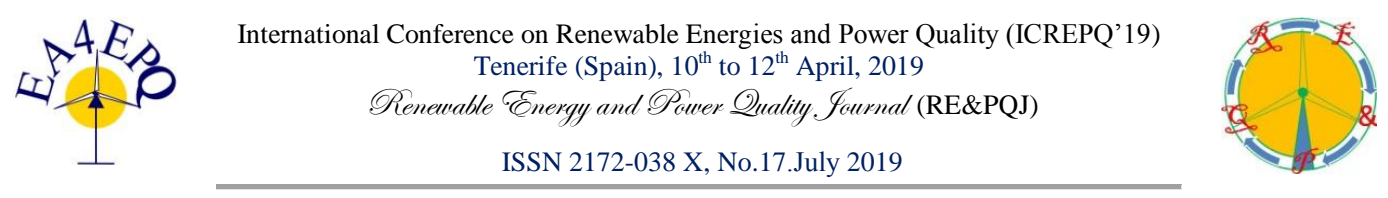

\title{
Evaluation of Energy Sources Capable of Drought/Famine Abatement in an African Village
}

\author{
M. Alrefai ${ }^{1}$ and A. Pourmovahed ${ }^{2}$ \\ ${ }^{1}$ Mechanical Engineering Department - Graduate Student \\ Phone number: 001810447 5820, e-mail: eng.malrefai@gmail.com \\ ${ }^{2}$ Professor of Mechanical Engineering \\ Phone number: 001810 762-9758, e-mail: apourmov@ kettering.edu \\ Kettering University \\ Flint, Michigan, U.S.A. 48504
}

\begin{abstract}
With the extreme drought attacking the Horn of Africa continuously for the past few years, more than 22 million people are facing famine and are in danger of starvation. According to the UN Office for the Coordination of Humanitarian Affairs (OCHA), it is the worst drought occurring in all of East Africa in 60 years. Countries affected by the drought are Somalia, Djibouti, Ethiopia, Kenya, Uganda and neighboring countries. In most rural areas, lack of access to sufficient power has aggravated the disastrous conditions. In this investigation, a small East Ethiopian village of 500 inhabitants was analysed to determine the water required for drinking, personal hygiene as well as food production. A sustainable power source was identified and selected for the purpose of powering a water pump as well as providing nightly lighting for this village. Sustainable funding sources were also considered. Total system cost including a wind turbine system, pumps, piping, water storage tank, battery storage system, backup diesel generator and fuel tank as well as the solar lighting system was estimated at about USD 90,000.
\end{abstract}

\section{Key words}

East African Drought, Wind Power Famine Abatement, Rural Development, Village Water Supply

\section{Introduction}

Starting around 2011 when some East African countries were already suffering from the consequences of conflicts and war, a catastrophic drought affected the region and has continuously persisted. The suffering is especially tragic since most of the residents of the affected countries live in rural areas with little access to energy resources required to support their basic needs.

For many decades, vast regions in east Africa have been suffering from droughts, conflicts, disease, and corruption [1]. Wide areas of this region are declared as disaster areas in need of emergency food and medical supplies (Fig. 1).

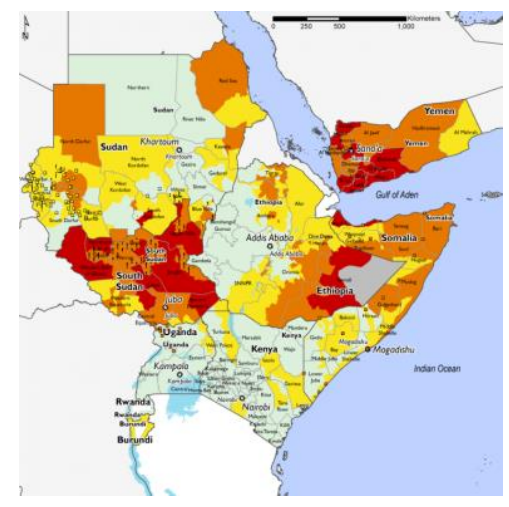

Fig. 1. Map of East Africa indicating high levels of food insecurity in summer, 2018. Areas in red are experiencing emergency levels of hunger [1].

People in the affected areas are in need of immediate help and support to overcome malnutrition and shortage of clean drinking water. Humanitarian agencies are responding by collecting donations and delivering food and other supplies to these areas and are trying to save as many lives as possible. In the long run, serious development programs need to be undertaken to help residents to achieve self- 
sufficiency. It should be clear that access to sustainable power supplies is essential for any long term development.

In this study, we selected a simple, inexpensive and sustainable energy system to provide sufficient power to a small village of 500 inhabitants located in Eastern Ethiopia (Fig. 2). The power will be used primarily for the purpose of pumping water out of a deep well, to be used for drinking, personal hygiene, crop irrigation and raising livestock. A simple solar system was also considered in order to provide lighting. The system implemented must be reasonably priced and require minimal maintenance without the need for highly skilled technicians.

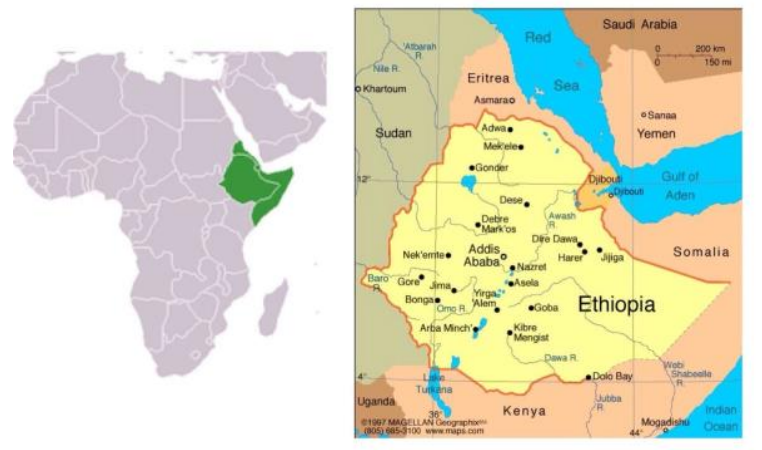

Fig. 2. Ethiopia within the Horn of Africa (shown in green). Sources: Wikipedia and InfoPlease.com

\section{Assumptions and water requirements}

To keep the human body healthy, an appropriate balanced diet comprised of water, carbohydrates, proteins, fats as well as vitamins is needed. The number of kcal needed per person varies depending on age and gender. On average, the requirement for one person is $2000 \mathrm{kcal}$ per day. Estimated daily water requirement for drinking and personal hygiene is about 20 liters per person.

Tables I and II show the basket of crops and the livestock selected for the village based on nutrition requirements, local culture and traditions [2].

Table I. - Selected crops for the village

\begin{tabular}{|l|c|c|c|}
\hline Crop & $\begin{array}{c}\text { Yield } \\
\mathrm{kg} / \mathrm{ha}\end{array}$ & $\begin{array}{c}\text { Protein } \\
\mathrm{kg} / \mathrm{ha}\end{array}$ & $\begin{array}{c}\mathrm{Kcal} \\
/ \mathrm{m}^{2}\end{array}$ \\
\hline barley & 2,777 & 347 & 982 \\
\hline chick peas & 760 & 147 & 275 \\
\hline maize & 5,109 & 415 & 1,847 \\
\hline potatoes & 17,268 & 345 & 1,318 \\
\hline sorghum & 1,459 & 165 & 529 \\
\hline sweet potatoes & 13,467 & 211 & 1,140 \\
\hline teff & 1,700 & 226 & 605 \\
\hline wheat & 3,086 & 423 & 1,083 \\
\hline
\end{tabular}

Table II. - Selected livestock

\begin{tabular}{|c|c|c|c|}
\hline Livestock & Quantity & Purpose & Products \\
\hline Camel & 70 & $\begin{array}{c}\text { Transportation } \\
\text { and Meat }\end{array}$ & $\begin{array}{c}\text { Transportation } \\
2 / \text { month for } \\
\text { meat }\end{array}$ \\
\hline $\begin{array}{c}\text { Zebu } \\
\text { (Fig. 3) }\end{array}$ & 150 & Meat & $\begin{array}{c}8 / \text { month for } \\
\text { meat }\end{array}$ \\
\hline Goat & 300 & Meat and milk & $\begin{array}{c}600 \text { 1/day milk } \\
20 / \text { month for } \\
\text { meat }\end{array}$ \\
\hline Chicken & 1000 & $\begin{array}{l}\text { Meat and } \\
\text { eggs }\end{array}$ & $\begin{array}{c}500 \text { eggs/day } \\
500 / \text { month } \\
\text { for meat }\end{array}$ \\
\hline
\end{tabular}

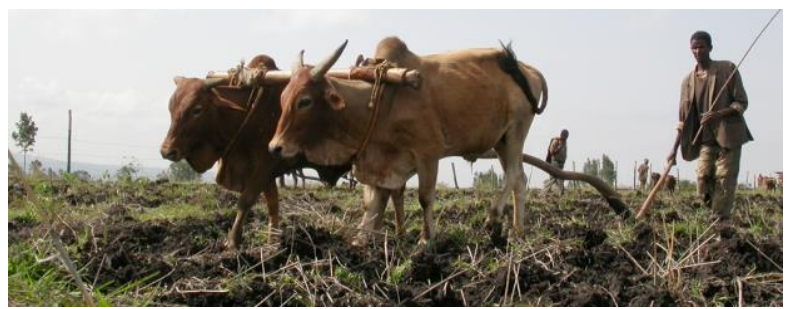

Fig. 3. Zebu (humped cattle) can tolerate extreme heat. Source: http://www.aidethiopia.com/Switzerland.html

Table III summarizes the estimated water requirements for the village [3].

Table III. - Water needs of the village of 500 inhabitants

\begin{tabular}{|l|c|c|c|}
\hline Used for & Liters/day & Liters/year & $\%$ of total \\
\hline Humans & 10,000 & $3,650,000$ & 1.4 \\
\hline Livestock & 9,850 & $3,595,250$ & 1.4 \\
\hline Crops & 690,500 & $252,032,500$ & 97.2 \\
\hline \hline Total & 710,350 & $259,277,750$ & 100 \\
\hline
\end{tabular}

It is not surprising that the estimated water requirement for crop irrigation by far exceeds the amounts needed for human consumption and raising livestock.

\section{The water system}

Depth of groundwater varies significantly throughout Ethiopia. In the area selected for this study, water well depth is in the range of 177-292 $\mathrm{m}$ and depth to water is 81.1-207 $\mathrm{m} \mathrm{[4].} \mathrm{To} \mathrm{be} \mathrm{conservative,} \mathrm{we} \mathrm{assumed}$ that water is pumped from a depth of $250 \mathrm{~m}$ with a flow rate of 500 liters per minute $(720,000$ liters/day) and with a pump head of $320 \mathrm{~m}$, enough to lift the water $250 \mathrm{~m}$ and overcome frictional losses in a 6-inch steel pipe (Fig. 4). 


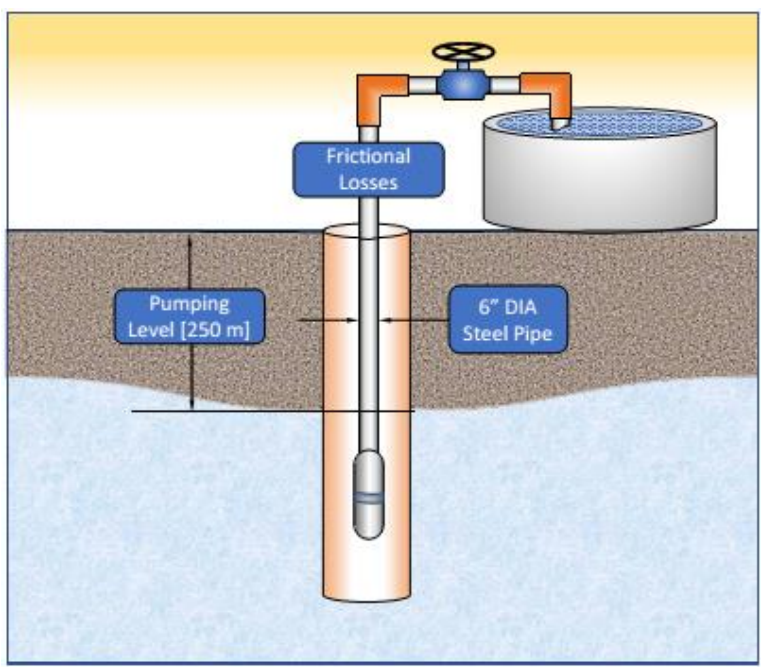

Fig. 4. The submersible water pump and piping system.

A submersible pump is available with a flow rate of 650 liters/min at a head of $320 \mathrm{~m}$ with a $50 \mathrm{HP}$ (37 $\mathrm{kW})$ electric motor. This motor requires a minimum 100 KVA electric source to start. The cost for two pumps (one installed and one as a spare) is USD 9,050.

Water storage of 100,000 liters is recommended. This volume is enough to cover the human and livestock water needs for 5 days. An inexpensive and reliable PVC storage tank is available at a cost of USD 3,000 for one 50,000-liter unit.

\section{Power system selection}

The power system selected for pumping water needs to be adequate, satisfactory, sustainable and available at a relatively low initial cost. In addition, it must have a low operational cost along with a minimum need for highly technical expertise to operate and maintain the system. Also needed is a backup system capable of handling emergency situations and malfunctions.

If a central system were selected to supply the village with both water and lighting, it would require a lot of costly infrastructure and a number of highly skilled technicians to operate and maintain the system. Therefore, it was decided to use a simple method to provide the required lighting separately.

It is very critical to have a reliable and safe power supply system that can keep the water flowing. A multitude of power systems were considered to operate the water pump. A backup generator was also included in order to deal with emergency and unusual situations.

Fuel cell systems were quickly ruled out as they are quite expensive and require significant maintenance as well as a reliable and sustainable fuel supply, and are not practical based on the location of this village.

Solar energy was considered as a possible sustainable source of power for this application. Ethiopia is in a tropical region, between latitudes $3^{\circ}$ and $15^{\circ} \mathrm{N}$. Its solar potential is high especially in the southeast region [5] as shown in Fig 5.

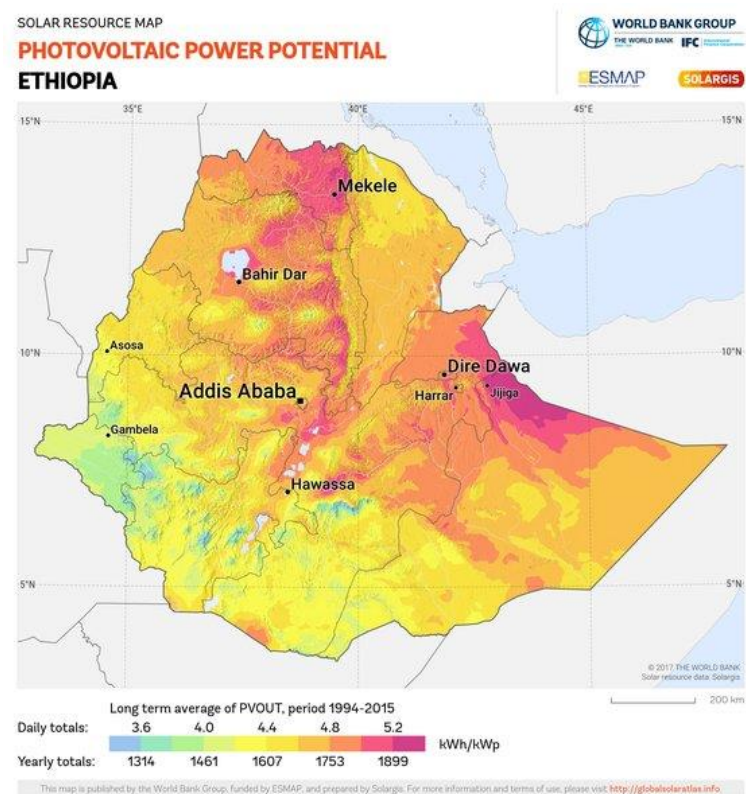

Fig. 5. Photovoltaic power potential for Ethiopia. Source: The World Bank, Solar resource data- Solargis [5].

To construct a photovoltaic power station large enough to power the water pump $(37 \mathrm{~kW} \times 24 \mathrm{~h} /$ day $=888$ $\mathrm{kWh}$ daily total) at $4.6 \mathrm{kWh} / \mathrm{kWp}$, a peak power of 193 $\mathrm{kWp}$ is required. The current PV panel price is about USD 3/Wp. This means that a solar system for this application can cost as much as USD 580,000.

Being located in an arid desert area, the solar PV panels will be exposed to dust and sand. The panels need to be cleaned and maintained frequently in order to sustain the desired output of the system. This requirement and the massive initial cost make the solar option impractical. Other energy sources including geothermal, biogas and natural gas were also eliminated for obvious reasons.

As shown in Fig. 6, Eastern Ethiopia has a high wind potential [6] with a mean velocity range from $8-12 \mathrm{~m} / \mathrm{s}$ [7], hence it was decided to consider using a wind turbine system to provide the power needed for pumping water $(37 \mathrm{~kW})$. Generally, wind turbines do not require high maintenance or a great deal of operational technical expertise after installation. A cheaper, less complex power source would be the 
gasoline or diesel engine from a used vehicle but this will require regular fuel deliveries to the village, not a practical option in a generally hostile environment.

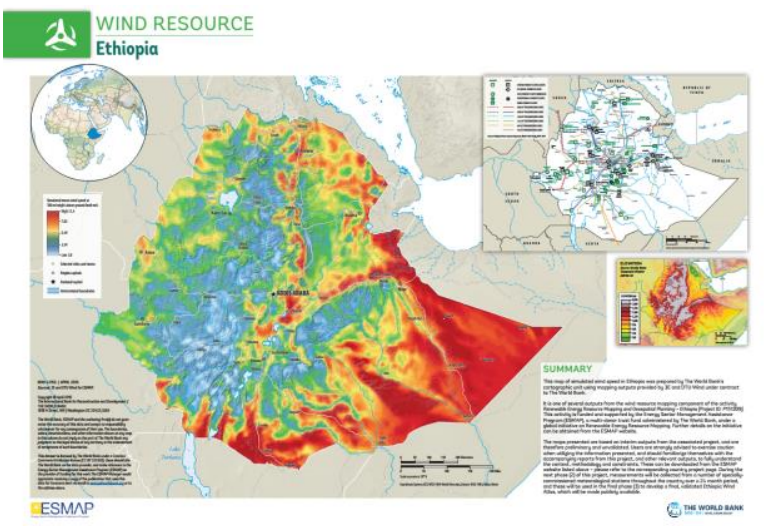

Fig. 6. Ethiopia wind map.

Source: The World Bank [7]

Wind turbine generators are available in many different sizes. Assuming an efficiency of 32\% (maximum theoretical efficiency is 59.3\%), an available turbine with a $22 \mathrm{~m}$ diameter can provide an output power of about $37 \mathrm{KW}$ at $8 \mathrm{~m} / \mathrm{s}$ rated wind speed with a low speed start up (about $2.5 \mathrm{~m} / \mathrm{s}$ wind speed). The estimated cost for this size turbine including installation is about USD 42,000.

To provide energy storage for the water pump, a battery bank and control system will be required in order to stabilize current flow to the water pump. The estimated price for this system is USD 21,200. A backup diesel generator (USD 4,000) was also included as a simple and inexpensive solution for emergency needs. With a 2,000-L diesel tank (USD 1,400 filled up with fuel), it can run continuously for about 28 days.

The system components and their estimated cost are shown in Table IV.

\section{The lighting system}

A simple lighting system was selected to cover the basic lighting needs of the villagers for a few hours in the evening and during early morning hours. For ease of use and to eliminate the cost of constructing an electric grid or any electric infrastructure and to minimize any maintenance work, two solar rechargeable lanterns were selected for each household. Additionally, five solar light poles were included to illuminate public areas. One advantage of using solar lanterns is that they can be used safely by any person and there is no need for any wiring or harnessing work. Each lantern can recharge itself easily by being exposed to sunlight for a few hours. The solar light poles are also self-operating units. They are easy to install. Once installed, they will recharge automatically.

The solar lights are available with an estimated total cost of USD 4,500 for two lanterns per household and five solar light poles.

Table IV. - System components and their estimated cost

\begin{tabular}{|l|c|}
\hline Component & $\begin{array}{c}\text { Estimated } \\
\text { cost (USD) }\end{array}$ \\
\hline $\begin{array}{l}\text { Water Pumps (2), one is spare } \\
\text { each: 650 liters/min, 320 m head } \\
\text { 50 HP (37 kW) electric motor }\end{array}$ & 9,050 \\
\hline Steel Pipe, 1000 ft, 6-inch diameter & 1,100 \\
\hline $\begin{array}{l}\text { PVC Water Storage Tanks } \\
2 \text { x 50,000 liters }\end{array}$ & 6,000 \\
\hline $\begin{array}{l}\text { Wind Turbine System } \\
\text { 37 KW at 8 m/s wind speed } \\
22 \text { m impeller diameter }\end{array}$ & 42,000 \\
\hline $\begin{array}{l}\text { Battery Storage and Control System } \\
\text { 41.5 kWh capacity }\end{array}$ & 21,200 \\
\hline $\begin{array}{l}\text { Diesel Generator (backup) 100 KVA } \\
\text { Fuel consumption: 215 g/kWh } \\
\text { Estimating use: 450 hours/year } \\
\text { Yearly fuel consumption: 130 L }\end{array}$ & 4,000 \\
\hline $\begin{array}{l}\text { Diesel Fuel Tank, 2000 liters } \\
\text { USD 200 for the storage tank } \\
\text { + USD 1,200 for 1 fill up }\end{array}$ & \\
\hline $\begin{array}{l}\text { Lighting (200 LED solar lanterns + } \\
\text { 5 solar light poles) }\end{array}$ & 4,400 \\
\hline Total Estimated Cost & $\mathbf{8 9 , 2 5 0}$ \\
\hline
\end{tabular}

\section{Potential funding sources}

As seen above, supplying a village of 500 people in Eastern Ethiopia with water and lighting is not cost prohibitive. The USD 89,250 required for providing sustainable food supplies and sufficient water for drinking and personal hygiene as well as lighting may potentially come from a variety of sources including but not limited to:

- Sustainable Energy Fund for Africa (SEFA)

- Maendeleo Agricultural Enterprise Fund

- Farm Capital Africa Limited

- African Agriculture Fund

\section{Summary and concluding remarks}

It is distressing to see millions of people starve and die from hunger in the $21^{\text {st }}$ century. To provide much 
needed water - most of which is used for food production - to communities affected by drought, it is critical to have a sufficient and sustainable power supply particularly for long term development projects. Various types of sustainable power systems should be considered and tailored to each situation based on the geographic location of the project. It is imperative to choose a relatively simple system at a reasonable cost.

In this study, a sustainable energy system using a single wind turbine system was selected to supply water to a village with a population of 500 in Eastern Ethiopia. A modest solar PV system will provide sufficient lighting.

The wind-powered water system is capable of providing sufficient water (500 liters per minute) for agriculture (97.2\%), drinking and personal hygiene (1.4\%) and raising livestock (1.4\%). The lighting system selected consists of 200 LED solar lanterns (2 per household) as well as 5 solar light poles used to illuminate public areas.

The total system cost was estimated at about USD 90,000 It is anticipated that the required funding can be obtained from one or a multitude of international aid institutions or foundations.

A simpler and less expensive option is to use a gasoline or diesel engine from a used vehicle to power the pump. However, this would require fuel deliveries to the village on a regular basis, not a practical option in a hostile environment.

The budget shown in Table IV does not include the cost of digging a $270 \mathrm{~m}$ deep well, including the wall ( $\approx$ USD 27,000), or acquiring a heavy duty farming tractor $(\approx$ USD 20,000), livestock, seeds or fertilizers.
Relocating the villagers to a less arid, fertile area or using hydroponics to reduce water requirements were beyond the scope of this study.

\section{References}

[1] World Vision: East Africa hunger, famine: Facts, FAQs, and how to help https://www.worldvision.org/hungernews-stories/East-africa-hunger-famine-facts

[2] Garden Places, For the Nutrition per Hectare Series of Articles http://www.gardeningplaces.com/articles/nutrition-perhectare1.htm

[3] PennState Extension, Water System Planning: Estimating Water Needs https://extension.psu.edu/water-system-planningestimating-water-needs

[4] S. Amer, A. Gachet, W. Belcher, J. Bartolino and C. Hopkins, "Groundwater Exploration and Assessment in the Eastern Lowlands and Associated Highlands of the Ogaden Basin Area, Eastern Ethiopia: Phase 1 Final Technical Report," https://water.usgs.gov/international/final_approved_vers ion-090414.pdf

[5] SOLARGIS

https://solargis.com/maps-and-gisdata/download/ethiopia

[6] The Africa Report, Ethiopia has huge wind energy potential http://www.theafricareport.com/East-HornAfrica/ethiopia-has-huge-wind-energy-potential.html

[7] http://pubdocs.worldbank.org/en/992231461105688203/ Ethiopia-Wind-Resource-Poster-Landscape-WBESMAP-Apr2016.pdf 